\title{
Multiple Intelligences and Attachment among University Students and Their Influence on Life Satisfaction and Happiness
}

\author{
Serpil Aytac ${ }^{\# 1}$, Nazan Bilgel ${ }^{* 2}$ \\ ${ }^{\# 1}$ Prof. Dr. Faculty of Economics and Administrative Sciences, Department of Labor Economics and Industrial \\ Relations, Uludag University Bursa, Turkey \\ ${ }^{* 2}$ Prof. Dr. Faculty of Medicine, Department of Family Medicine, Uludag University, Bursa, Turkey
}

\begin{abstract}
This study is about the types of multiple intelligences and attachment styles among a group of Turkish university students. Participants were 450 students from one public university in Turkey. A demographic and socio-economic questionnaire, Multiple Intelligence Survey, Revised Adult Attachment Scale, Satisfaction with Life Scale and The Oxford Happiness Questionnaire -short version were used as study instruments. Of the 450 students, $63.8 \%$ were female and the mean age was $21.24 \pm 2.14$ years. Bodily intelligence was reported more frequently by male students whereas intrapersonal and logical intelligences were reported at higher rates in female students. Attachment related avoidance was reported by $58.7 \%$ of the students. Male students reported more attachment related anxiety, and female students reported more attachment related avoidance. No significant correlations were determined between attachment style and economic status, age, class-year and Grade Point Average of the students. The relationship between students' intelligence and attachment style was also insignificant. No significant relationship was determined between the happiness and life satisfaction scores of students with different types of intelligences. Female students were found to be significantly happier and satisfied with their lives than male students. Students with a poor economic status had the lowest happiness and life satisfaction scores and the difference was statistically significant. These findings are important to provide a more complete picture about the difficulties experienced by young adults when socially or emotionally adapting to university life. There is much to say regarding the impact of "multiple intelligences", "attachment styles" and the "subjective well-being" of university students.
\end{abstract}

Keywords - Multiple intelligences, Adult attachment, Life satisfaction, Happiness, University students.

\section{INTRODUCTION}

Intelligence; it can be defined as the ability to understand complex thoughts, adapt to the environment, produce new solutions from those learned, participate in various forms of reasoning and overcomes obstacles by thinking [1].

The concept of multiple intelligence is an approach developed by Howard Gardner, a psychologist from Harvard University [2] [3]. According to Gardner, there are nine different bits of intelligence that is Bodily/Kinesthetic, Interpersonal, Intrapersonal, Existential, Logical/Mathematical, Naturalist, Verbal/Linguistic, Musical, and Visual/Spatial [2] [3]. Gardner defined this nine bits of intelligence as follows:

- Bodily/Kinesthetic Intelligence is the ability to use the body to create or change things and the competence to express ideas and feelings in a physical way.

- Interpersonal Intelligence is the ability to perceive emotions, intentions, motivations and moods in others.

- Intrapersonal Intelligence is the competency of knowing oneself and having an intrinsically developed positive self-concept and life direction.

- Existential Intelligence refers to spiritual appreciation and comprehension and exploration of questions about life and human existence in the universe.

- Logical/Mathematical Intelligence is proficiency in working with numbers, and manipulating them together with the skill of reasoning.

- Naturalistic Intelligence is the competence of recognizing, classifying, explaining, categorizing, and thinking about living organisms in Nature.

- Verbal - Linguistic Intelligence is the competence of using language effectively, to think about words and sounds, to grasp complex meanings, to persuade people, to recognize different structures in language, to create new structures, and to deal with different linguistic patterns 
- Musical Intelligence is the ability to recognize different voices and produce new sounds, rhythms, and to perform with the appreciation of sounds and notes, recognizing and using concepts, and being sensitive to voices and musical instruments.

- Visual/Spatial Intelligence is the ability to think in terms of pictures and shapes, to perceive the visual world, to see shapes, colors and textures with the eyes of the mind and to convert them into artistic forms [2] [3].

The objectives of this study are summarized in the following questions:

1) What types of Multiple Intelligences are common among Turkish students? Is there any relationship between social, demographic and economic characteristics and type of intelligence?

2) What types of attachment styles are seen frequently among Turkish students and is there a relationship between type of intelligence and attachment style?

3) Is there any relationship between the type of intelligence and life satisfaction and happiness?

4) Is there any relationship between the type of attachment and life satisfaction and happiness?

\section{LITERATURE REVIEW}

According to Gardner in adult learning, individuals should be understood and articulate their learning preferences which are specified by their intelligences [3]. Therefore, identifying Multiple Intelligences of university students is an important issue. It is now recognized by many educators that each student is different and there is a need to modify teaching methods to incorporate Multiple Intelligences. A tool based on Gardner's theory (1993) to identify Multiple Intelligences was developed by McClellan and Conti [4].

McClellan and Conti determined the preferred areas of Multiple Intelligences of 874 community college students to be: "Bodily/Kinesthetic Intelligence (19.1\%), Musical Intelligence (18.8\%), Logical/Mathematical Intelligence (13\%), Interpersonal Intelligence (10.8\%), Intrapersonal (8.2\%), Existential (7.7\%), Visual (4.6\%), Verbal (2.9\%), Naturalistic (1.5\%) and Mixed intelligence (13.4\%)" [4]. In a study of adult participants, Amiryousefi and Tavakoli (2011) found a relationship between kinesthetic and musical intelligences and listening and writing, respectively [5]. Fahim, Bagherkazemi and Alemi (2010) revealed that logical, bodily, linguistic and intrapersonal intelligences improve the reading abilities of students [6].

A study of Irish students, showed the rankings for the self-estimations of Multiple Intelligences and the highest levels were determined to be for interpersonal intelligence, followed by intrapersonal, verbal, existential, spatial, body/kinesthetic, logical/mathematical, spiritual, naturalistic, and musical intelligence [7].

There have been several studies from Turkey in literature regarding Multiple Intelligences in University Students. One of these indicated the Multiple Intelligences areas for 609 students studying educational sciences as follows: Intrapersonal 34.0\%, Existential 15.1\%, Logical/ Mathematical Intelligence 9.7\%, Interpersonal Intelligence $8.5 \%$, Bodily/Kinesthetic Intelligence 6.6\%, Musical Intelligence 4.8\%, Visual 3.4\%, Verbal $4.1 \%$, Naturalistic $1.5 \%$, and Mixed $12.3 \%$ [8].

The attachment styles are defined as the motivation systems that exist on the basis of interpersonal relationships, explaining how individuals interact and communicate with each other. Attachment is defined as an emotional bond in many sources, which develops in interpersonal, manifests itself in the search for closeness of the individual, which is particularly pronounced in stress situations, with consistency and continuity. Attachment theory was developed by Bowlby (1973) and focused predominantly on the child-parent relationship [9]. More recently, more general adult relationships have been included in attachment theory [10]. Bartholomew and Horowitz (1991) identified 4 major attachment styles of secure, fearful, preoccupied and dismissed [11]. These 4 styles are often represented in two major dimensions of attachment anxiety (anxious attachment) and attachment avoidance [12]. Of the four major attachment styles, the secure and preoccupied styles correspond to secure and anxious attachment, whereas the dismissed and fearful styles are a branch of avoidant attachment [48]. Anxious attachment typically manifests with low self-worth, and fear of rejection and abandonment, whereas avoidant attachment is characterized by discomfort with closeness, excessive self-reliance and lack of confidence in depending on others [12] [13].

A study of college students in the USA showed a decline of students with secure attachment style over time, and an increase in students with fearful, preoccupied and dismissed attachment styles [14]. In a study of Canadian college students, those with secure attachment styles were seen to be confident in their abilities, showed greater motivation and used effective learning strategies [15]. A study of 247 university students in Cyprus showed that the most seen attachment style was dismissing attachment whereas the least observed was preoccupied attachment [16]. Another study of Italian university students found the distribution of students in terms of their attachment styles as follows: $51.9 \%$ preoccupied, $36.3 \%$ secure, $7.4 \%$ dismissed and $4.4 \%$ fearful [17].

For many years, there have been attempts to define subjective well-being and explain its correlations and consequences [18] [19]. Happiness can be defined as a state of joy experienced frequently or as a state of satisfaction. These differ in that a state of joy is an emotion and being satisfied is cognition. Both cognition and 
emotions are emphasized in subjective measurements of well-being. Previous research has shown that better health and longevity result from life satisfaction, optimism, an absence of negative emotions and the presence of positive emotions [20] [21] [22]. There have been several studies of university students which have related attachment style and well-being. Shiota et al. (2006) reported that adult attachment anxiety was negatively associated with the positive emotions of joy [23]. A study of 1,622 students from different cultures found no significant correlation between secure attachment and subjective well-being [24]. Barry et al. (2007) reported that anxious and avoidant attachment was associated with higher levels of negative effect and lower levels of positive effect in comparison to university students with secure attachment [25]. In a study of 241 university students from Turkey and Germany, attachment anxiety in the German students and attachment avoidance in the Turkish students showed a stronger relationship with higher levels of psychological distress [26]. In a study by Jin and Wang (2016), it was reported that attachment avoidance directly predicted life satisfaction whereas attachment anxiety may predict life satisfaction indirectly [27]. A study of Iranian university students found a positive correlation between secure attachment style and life satisfaction [28].

\section{MATERIAL AND METHODS}

This is a cross-sectional and descriptive study. Approval for this study was granted by the Social and Humanities Research and Publications Ethics Committee of the University. (Approval no: 2017-12). The study was conducted between 5 January 2018 and 28 February 2018.

\section{A. Participants}

The participants of the study were students from the social sciences and health sciences departments of the corresponding university. Participation was voluntary and anonymous and all participants gave informed consent. During the regular courses, the purpose of the study was explained and questionnaires were distributed. Of the 500 distributed questionnaires, 15 were not returned and 35 questionnaires were excluded because of missing data. Thus, a total of 450 questionnaires were evaluated. The distribution and collection of all the questionnaires was done in closed envelopes.

\section{B. Instruments}

Demographic and socio-economic questionnaire: this gave details of the participant's age, gender, department, class- year, economic status and GPA (Grade Point Average).

Multiple Intelligence Survey (MIS): this was developed by McCellan and Conti (2008) and the Turkish adaptation and validation was performed by Babacan [8]. MIS was developed as a self-reporting questionnaire to identify Multiple Intelligences as described by Gardner. The MIS includes 27 items scored in a range of 3 to 27 with a midpoint of 15 . Participants rank all the items starting with 1 for the items that are the "most like them" through to 9 for the item "least like them". The scores are calculated for each participant in each Multiple Intelligences area by totaling the ranking for each of the three items in each area. Low scores indicate a strong Multiple Intelligences area while high scores indicate that the Multiple Intelligences area does not apply to the participant. Thus, the area with the lowest score is identified as that individual's preferred Multiple Intelligences area. The Turkish version of the MIS has been found to be valid and reliable [8].

Revised Adult Attachment Scale (RAAS): this was developed by Collins (1996) to measure how one generally feels in relationships with family members, romantic partners, and close friends. The scale is an 18 -item selfreporting measure, with three subscales, each comprised of six items [29]. The three subscales are "close", "depend" and "anxiety". The "close" subscale measures how comfortable a person is with intimacy and closeness. The "depend" subscale measures the extent to which a person feels he/she can depend on others to be available when needed and the "anxiety" subscale measures the extent to which a person is concerned that they have been rejected or disliked. Respondents rate each item on a 5-point Likert-type scale ranging from 1 (not at all characteristic of me) to 5 (very characteristic of me). Items are totaled to provide an overall mean for each participant, with higher average scores reflecting less stable adult attachment qualities. An alternative scoring of this instrument is also available which computes the two attachment dimensions and they are: attachment related anxiety (model of self) and attachment related avoidance (model of other). In adult attachment theory, there is no widely accepted conceptualization or measure of individual variation [10]. However, there is consensus that individuals can be characterized by their relative positions on two primary dimensions (attachment related anxiety and attachment related avoidance) that originate from the model of Bartholomew and Horowitz [11].

Since the RAAS has not been previously used or adapted to Turkish, the following procedure was applied for this study. First for the language translation, the scale was translated by the authors from English into the target language of Turkish. Then, it was translated back from the target language into the source language by another bilingual translator who was not involved in the original translation. Finally, the first and second translations were compared, by an expert panel comprising a bilingual health professional, a bilingual English teacher and a bilingual psychologist, none of whom were involved in the study. This expert panel identified and corrected any word usage discrepancies. The relevance and comprehensibility of the items were checked by a pilot study on 
20 students. The scoring of the RAAS in this study was made on the basis of two attachment dimensions: attachment related anxiety and attachment related avoidance. In this study, the reliability coefficients were found to be 0.75 for attachment related anxiety and 0.63 for attachment related avoidance.

Satisfaction with Life Scale (SWL): this was developed by Diener, Enmors, Larsen and Griffin (1985) and was adapted and validated for the Turkish language by Koker (1991). This scale consists of 5 items which are answered by using the scale between 1 and $7.1=$ not at all for me and $7=$ too much or too much for me (score range 5-35). .Higher scores indicate higher levels of life satisfaction [30] [31]. In this study the reliability coefficient was found to be 0.74 .

The Oxford Happiness Questionnaire -short version $(O H Q-S)$ : this was developed by Hills and Argyle (2002) and adapted and validated for the Turkish language by Seker and Gencdogan (2006) [32] [33]. The Turkish version has been shown to have good reliability and validity [34]. The scale consists of 7 items answered using a 1 - 6 scale, where $1=$ did not apply to me at all, and $6=$ applied to me very much or most of the time (possible score range 7-42). Higher scores indicate higher levels of happiness. In this study the reliability coefficient was found to be 0.67 .

\section{Statistical Analysis}

Statistical analyses of the study data were performed using IBM SPSS for Windows 23.0 software. In addition to descriptive statistics and internal reliability indices, $\chi 2$ analyses, ANOVA and t-tests were also applied.

\section{RESULTS}

Of the 450 students, $63.8 \%$ were female, $71.3 \%$ reported a moderate economic status and $15.8 \%$ were freshmen, $30.4 \%$ sophomore, $20.2 \%$ junior and $33.6 \%$ senior students. Most of the participants were studying social sciences. The mean age was 21.24 \pm 2.14 years. The mean GPA (Grade Point Average) was 2.53 \pm 0.55 with a range of 1.00-3.88. The distribution of the students according to their multiple intelligences and gender is shown in Table 1.

\section{Table 1. Students'Percent (\%) Distribution by Gender and Multiple Intelligences}

\begin{tabular}{|l|l|l|l|}
\hline & Male & Female & Total \\
\hline Bodily & 12.9 & 4.5 & 7.6 \\
\hline Existential & 8.6 & 10.1 & 9.6 \\
\hline Interpersonal & 6.1 & 3.8 & 4.7 \\
\hline Intrapersonal & 15.3 & 19.2 & 17.8 \\
\hline Logical & 7.4 & 16.4 & 13.1 \\
\hline Musical & 4.3 & 4.9 & 4.7 \\
\hline Naturalistic & 6.7 & 5.2 & 5.8 \\
\hline Verbal & 9.8 & 8.4 & 8.9 \\
\hline Visual & 3.1 & 5.6 & 4.7 \\
\hline Mixed & 25.8 & 22.0 & 23.3 \\
\hline Total & 36.2 & 63.8 & 100.0 \\
\hline
\end{tabular}

A statistically significant difference was determined between the genders in terms of multiple intelligences. Bodily intelligence was reported more frequently by male students whereas intrapersonal and logical intelligences were reported at higher rates in female students $(\chi 2=21.12 \mathrm{df}=9 \mathrm{p}=0.012)$. No statistically significant correlation was determined between multiple intelligences and economic status, age, class-year and GPA of the students.

This study revealed that $58.7 \%$ of the students reported an attachment related avoidance, which is characterized by discomfort with closeness, excessive self-reliance and lack of confidence in depending on others. A statistically significant difference was determined between the genders in respect of attachment style. Male students reported more attachment related anxiety, and female students reported more attachment related avoidance $(\chi 2=13.76 \mathrm{df}=1 \mathrm{p}=0.000)$. No significant correlations were determined between attachment style and economic status, age, class-year and GPA of the students. The relationship between students' intelligence and attachment style was also insignificant. Table 2. shows the distribution of students according to gender and attachment styles. 
Table 2. Students by Gender and Attachment Styles

\begin{tabular}{|l|l|c|c|}
\hline & \multicolumn{2}{|c|}{ Attachment Styles } & Total \\
\hline Male & \multicolumn{1}{|c|}{ Anxiety } & Avoid & \\
\hline Female & $86(52.8)^{*}$ & $77(47.2)$ & $163(100.0)$ \\
\hline TOTAL & $100(34.8)$ & $187(65.2)$ & $287(100.0)$ \\
\hline
\end{tabular}
*Numbers in ( ) are percentages
Num

The descriptive statistics for OHQ and SWL scores are shown in Table 3. No significant differences were determined in terms of the OHQ and SWL scores of students with different attachment types.

Table 3. OHQ and SWL Scores of Students by Attachment Types and Intelligence

\begin{tabular}{|l|l|l|l|l|l|l|l|l|}
\hline & & N & Mean & SD & 95\% CI & Minimum & Maximum \\
\hline & $\begin{array}{l}\text { Attachment } \\
\text { Type }\end{array}$ & & & & Lower & Upper & & \\
\hline OHQ & & & & & & & & \\
\hline & Anxiety & 186 & 23.29 & 3.50 & 22.78 & 23.80 & 14.00 & 33.00 \\
\hline & Avoid & 264 & 23.85 & 3.98 & 23.37 & 24.33 & 7.00 & 35.00 \\
\hline & TOTAL & 450 & 23.62 & 3.80 & 23.27 & 23.97 & 7.00 & 35.00 \\
\hline SWL & & & & & & & & \\
\hline & Anxiety & 186 & 19.37 & 5.90 & 18.51 & 20.22 & 7.00 & 35.00 \\
\hline & Avoid & 264 & 19.76 & 5.97 & 19.04 & 20.49 & 9.00 & 35.00 \\
\hline & TOTAL & 450 & 19.60 & 5.94 & 19.05 & 20.15 & 7.00 & 35.00 \\
\hline
\end{tabular}

Table 4. shows the OHQ and SWL scores of students with different intelligences. No significant relationship was determined between the OHQ and SWL scores of students with different types of intelligences.

Table 4. OHQ and SWL Scores of Students according to the Multiple Intelligences area

\begin{tabular}{|l|l|l|l|l|l|l|l|l|}
\hline & & $\mathbf{N}$ & Mean & SD & 95\% CI & Minimum & Maximum \\
\hline & Intelligence & & & & Lower & Upper & & \\
\hline OHQ & & & & & & & & \\
\hline & Bodily & 34 & 23.32 & 3.85 & 21.97 & 24.67 & 19.00 & 33.00 \\
\hline & Existential & 43 & 22.81 & 4.51 & 21.42 & 24.20 & 13.00 & 35.00 \\
\hline & Interpersonal & 21 & 24.14 & 3.16 & 22.70 & 25.58 & 18.00 & 30.00 \\
\hline & Intrapersonal & 80 & 23.53 & 4.23 & 22.59 & 24.48 & 7.00 & 33.00 \\
\hline & Logical & 59 & 23.66 & 3.40 & 22.77 & 24.55 & 14.00 & 29.00 \\
\hline & Musical & 21 & 23.71 & 2.43 & 22.60 & 24.82 & 20.00 & 29.00 \\
\hline & Naturalistic & 26 & 22.61 & 4.94 & 20.62 & 24.61 & 11.00 & 31.00 \\
\hline & Verbal & 40 & 23.12 & 2.58 & 22.29 & 23.95 & 17.00 & 30.00 \\
\hline & Visual & 21 & 23.62 & 4.09 & 21.75 & 25.48 & 14.00 & 30.00 \\
\hline & Mixed & 105 & 24.41 & 3.65 & 23.71 & 25.13 & 16.00 & 33.00 \\
\hline & & & & & & & \\
\hline & Bodily & 34 & 18.17 & 5.80 & 16.15 & 20.20 & 10.00 & 30.00 \\
\hline & Existential & 43 & 19.18 & 4.43 & 17.82 & 20.55 & 13.00 & 35.00 \\
\hline & Interpersonal & 21 & 18.52 & 3.93 & 16.73 & 20.31 & 11.00 & 26.00 \\
\hline & Intrapersonal & 80 & 20.42 & 6.21 & 19.04 & 21.80 & 10.00 & 35.00 \\
\hline & Logical & 59 & 21.13 & 6.69 & 19.39 & 22.88 & 7.00 & 33.00 \\
\hline & Musical & 21 & 18.71 & 4.49 & 16.67 & 20.76 & 12.00 & 29.00 \\
\hline & Naturalistic & 26 & 17.30 & 5.26 & 15.18 & 19.43 & 9.00 & 30.00 \\
\hline & Verbal & 40 & 19.50 & 6.17 & 17.52 & 21.47 & 10.00 & 35.00 \\
\hline & Visual & 21 & 18.52 & 4.65 & 16.40 & 20.64 & 10.00 & 29.00 \\
\hline & Mixed & 105 & 19.97 & 6.54 & 18.70 & 21.23 & 9.00 & 35.00 \\
\hline
\end{tabular}

Female students were found to be significantly happier and satisfied with their lives than male students. Students with a poor economic status had the lowest OHQ and SWL scores and the difference was statistically significant. Students with higher GPA were more satisfied with their lives than those with lower points but no significant difference was determined in terms of happiness. No significant differences were determined between students of different ages and class years in respect of happiness and life satisfaction.

\section{DISCUSSION}

The primary aim of this study was to determine the types of common multiple intelligences among university students and the first three most common areas were reported to be intrapersonal, logical and existential intelligences, respectively. Significant differences were determined between female and male students according 
to the types of highly reported intelligences. For male students the top three intelligences were intrapersonal, bodily and verbal intelligences whereas female students reported intrapersonal, logical and existential intelligences. The least reported intelligences were musical, interpersonal and visual intelligences for the whole study group, visual, musical, and interpersonal for the male students and interpersonal, bodily and musical intelligences for the female students. Previous studies of Turkish university students have found intrapersonal intelligence to be the highest reported intelligence and naturalistic intelligence to be the lowest [8]. Furthermore, those studies showed significant differences between the genders in respect of visual, musical [35] and logical intelligences [36]. In contrast, another study found no differences according to gender in any intelligence area [37]. Intrapersonal intelligence was the highest reported intelligence in the current study and this result is consistent with previous studies, but the lowest reported intelligences were different and in the current study these were visual, interpersonal and musical intelligences whereas the difference between the genders was due to bodily and logical intelligences. Previous studies from other parts of the world have shown gender differences favoring males in intelligence domains of logical and visual [38] [39] [40] [41]. Ekici et al. (2012) found a significant positive relationship between age and logical intelligence and a negative relationship between age and musical intelligence but the current study revealed no such relationships [35]. The highly reported intrapersonal intelligence in the current study refers to self-knowledge and the ability to use that knowledge effectively.

The students in this study group are aware of their strengths and weaknesses and can utilize this knowledge effectively to plan and manage their lives [42] [43]. However, interpersonal intelligence, which is important in social relationships, understanding others and developing empathetic skills, was among the least reported types of intelligence. Interpersonal intelligence enables individuals to communicate with others and to get along with them. It allows people to work effectively with others. Activities such as role plays, group discussion, pair work, debates, and case studies that require students to interact and work with other people could be helpful in developing interpersonal intelligence.

More than half the students in the current study group reported avoidance type of attachment. Among the female students this proportion was higher than that of the whole group. This type of attachment refers to feeling independent, self-sufficient and comfortable without close emotional relationships and worrying about being hurt by others if close relationships are allowed. No significant relationships were determined between attachment type and multiple intelligence, life satisfaction and happiness. However, some studies have revealed these relationships. Kafetsios and Sideridis (2006) reported that anxious attachment and well-being were inversely associated and this was seen to be stronger in a younger age group than in an older group [44]. In a study of university students, Kankotan, (2008) demonstrated that the avoidance dimension of attachment, gender, and the anxiety dimension of attachment predicted life satisfaction [45]. Another study of Turkish and German university students found that attachment anxiety in the German sample and attachment avoidance in the Turkish sample showed a stronger association with higher levels of psychological distress [26]. According to Jin and Wang (2016), students with higher attachment anxiety developed more psychological distress [27]. Gnilka, Ashby, and Noble (2013) indicated that attachment anxiety and attachment avoidance were both negatively correlated with life satisfaction [46]. Another study found that both anxious and avoidant attachment had small negative direct effects on life satisfaction [47].

Although no significant relationship was determined in the current study between life satisfaction, happiness and multiple intelligences, it was observed that the lowest mean scores both for life satisfaction and happiness belonged to the students with naturalistic intelligence. Therefore, it can be assumed that the continuing and growing negative impact of mankind on Nature could have a disturbing effect on an individual's subjective well-being, although this is an issue which requires further research.

The main limitations of this study can be said to be that the sample cannot be generalized, the reliance on self-reporting measures, and that participants were expected to accurately recall their experiences. Moreover, in studies with cross-sectional design, it is difficult to establish causal inferences between variables. Repeated measures over time of key variables, such as multiple intelligences and attachment style would be useful to be able to verify their stability. Females constituted the majority $(63.8 \%)$ of the sample in this study, which was limited to the student population of one university. In future studies it would be of value to include a more representative sample from multiple universities from different regions of Turkey. The findings of this study can be considered of importance for those working with a student population and present a more comprehensive picture in respect of the challenges experienced by young adults when socially or emotionally adapting to university life. There is still much to be revealed in terms of the impact of multiple intelligences, attachment styles and the subjective well-being of university students. However, the results of this study can be considered of valuable guidance for further research on these issues. 


\section{ACKNOWLEDGMENT}

The authors thank Mrs. C.J. Walker for her assistance in proof-reading and editing of this manuscript.

\section{REFERENCES}

[1] Neisser, U., Boodoo, G., Bouchard, T.J., Boykin, A.W., Brody, N., Ceci, S.J., et al. Intelligence: knowns and unknowns. American Psychologist, 51, 1996, 77-101. http://dx.doi.org/10.1037/0003-066X.51.2.77

[2] Gardner, H. Frames of mind: The theory of multiple intelligences. New York, NY, Basic Books. 1983.

[3] Gardner, H. Multiple intelligences: The theory in practice. New York, NY, Basic Books. 1993.

[4] McClellan, J.A. \& Conti, G.J. Identifying the Multiple Intelligences of Your Students. Journal of Adult Education, 37, 2008, 13-32. https://www.questia.com/read/1P3-1593464571/identifying-the-multiple-intelligences-of-your-students

[5] Amiryousefi, M. Tavakoli, M. "The Relationship Between Test Anxiety, Motivation and MI and the TOEFL IBT Reading, Listening And Writing Scores". Procedia Social and Behavioral Sciences, 15, 2011, 210-214. http://dx.doi.org/10.1016/j.sbspro.2011.03.075

[6] Fahim,M., Bagherkazemi, M., M. Alemi The relationship between test takers' multiple intelligences and their performance on the reading sections of TOEFL and IELTS. Broad Research in Artificial Intelligence and Neuroscience, 1, 2010, 1-14. http://brain.edusoft.ro/index.php/brain/article/view/80/247

[7] Cruise, S.M., Lewis, C.A., Mc Cuckin, C. Examination Of Importance Ratings And Self-Estimates In Ten Domains Of Intelligence: Evidence Among A Sample Of UK And Irish University Students. The Irish Journal of Psychology, 30 (3-4), 2009, 171-183. http://dx.doi.org/10.1080/03033910.2009.10446308

[8] Babacan, T. "Sınıf Öğretmeni Adaylarının Üst bilişsel Okuma Stratejileri İle Çoklu Zeka Alanları Arasındaki İlişkinin İncelenmesi", Yüksek Lisans Tezi, Cumhuriyet Üniversitesi Eğitim Bilimleri Enstitüsü, Sivas [Searching the correlation between Metacognitive Reading Strategies and Multiple Intelligences of Primary School Teachers Candidates. Master’s Thesis, Sivas], 2012.

[9] Bowlby, J. Attachment And Loss: Vol. 2. Separation. New York, Basic Books. 1973.

[10] Crowell,J.A.,Fraley,R.C.,Shaver,P.R. Measurement Of Individual Differences In Adolescent And Adult Attachment. In: Cassidy,J.,Shaver,P.R.(Eds.),Handbook of Attachment: Theory, Research, and Clinical Applications, Second Edition. NewYork, Guilford Press, 2008, 599-634.

[11] Bartholomew,K., Horowitz, L.M. Attachment Styles Among Young Adults: A Test Of A Four-Category Model. Journal of Personality and Social Psychology, 61, 1991, 226-244. http://dx.doi.org/10.1037/0022-3514.61.2.226

[12] Brennan,K.A., Clark,C.L., Shaver, P.R. Self-Report Measurement Of Adult Attachment: An Integrative Overview. In J.A. Simpson, W.S. Rholes (Eds.), Attachment Theory and Close Relationships. New York, Guilford Press, 1998, 46-76

[13] Karantzas, G.C., Feeney, J.A., Wilkinson, R. Is less more? Confirmatory Factor Analysis Of The Attachment Style Questionnaires. Journal of Social and Personal Relationships, 27, 2010, 749-780. https://doi.org/10.1177/0265407510373756

[14] Konrath, S.H.,Chopik,W.J, Hsing, C.K., O’Brien, E. Changes in adult attachment styles in American college students over time: A meta-analysis. Personality and Social Psychology Review, 18, 2014, 326-348. http://dx.doi.org/10.1177/1088868314530516

[15] Beauchamp, G., Martineau, M., Gagnon,A. Examining The Link Between Adult Attachment Style, Employment And Academic Achievement In First Semester Higher Education. Social Psychology of Education, 19, 2016, 367-384. http://dx.doi.org/10.1007/s11218-015-9329-3

[16] Kuralp, F.S.,Serin, N.B. A study of students' loneliness levels and their attachment styles. Journal of Education and Training Studies, 5(7). 2017, 37-45. http://dx.doi.org/10.11114/jets.v5i7.2395

[17] Erriu, M.İ Ballarotto, G., Marzilli, E.,Cimino,S. \& Cerniglia, L. Attachment and Psychopathological Risk in Students Attending an Italian University. EC Psychology and Psychiatry, 4, 2017, 199-205. https://www.ecronicon.com/ecpp/pdf/ECPP-04-00137.pdf

[18] Diener E. Subjective Well-Being: Three Decades of Progress. Psychological Bulletin 125, 1999, 276-302.

[19] Argyle M. The Psychology of Happiness, 2nd edition. London, Routledge, 2001.

[20] Williams, R.B., Schneiderman, N. Resolved: Psychosocial Interventions Can Improve Clinical Outcomes In Organic Disease (pro). Psychosomatic Medicine 64, 2002, 552-557. http://dx.doi.org/10.1097/01.PSY.0000023410.02546.5D

[21] Xu, .J, Roberts, R.E. The power of positive emotions: It's a matter of life or death. Subjective well-being and longevity over 28 years in a general population. Health Psychology, 29, 2010, 9-19. http://dx.doi.org/10.1037/a0016767

[22] Diener, E.,\&Chan, M.Y. Happy People Live Longer: Subjective Well-Being Contributes To Health And Longevity. Applied Psychology Health Well Being, 3, 2011, 1-43. http://dx.doi.org/10.1111/j.1758-0854.2010.01045.x 
[23] Shiota, M. N., Keltner, D., \& John, O. P. Positive Emotion Dispositions Differentially Associated With Big Five Personality And Attachment Style. The Journal of Positive Psychology, 1, 2006, 61-71. http://dx.doi.org/10.1080/17439760500510833

[24] Galinha, I.C., Garcia-Martin, M.A., Oishi,S., Wirtz,D., \& Francisco Esteves,F. Cross-cultural comparison of personality traits, attachment security, and satisfaction -with relationships as predictors of subjective well-being in India, Sweden, and the United States. Journal of Cross-Cultural Psychology, 47, 2016, 1033-1052. http://dx.doi.org/10.1177/0022022116658262

[25] Barry, R. A., Lakey, B., \& Orehek, E. Links Among Attachment Dimensions, Affect, The Self, And Perceived Support For Broadly Generalized Attachment Styles And Specific Bonds. Personality and Social Psychology Bulletin, 33, 2007, 340-353. http://dx.doi.org/10.1177/0146167206296102

[26] Turan, N., Kocalevent,R.D., Quintana,S.M., Baker,O.E., \& Diestelmann, J. Attachment Orientations: Predicting Psychological Distress In German And Turkish Samples. Journal of Counseling \& Development, 94, 2016, 91-102. http://dx.doi.org/10.1002/jcad.12065

[27] Jin, L., \& Wang, C.D.D. International students' attachment and psychological well-being: the mediation role of mental toughness. Counseling Psychology Quarterly, 2016, http://dx.doi.org/10.1080/09515070.2016.1211510

[28] Komitaki, N.B.,Homaei,R. The investigation of the relationship between secure attachment style, self-efficacy, optimism and life satisfaction among the students of Ahvaz Islamic Azad University. International Journal of Humanities and Cultural Studies, 2, 2015, 1111-1122. http://www.ijhcs.com/index.php/ijhcs/index

[29] Collins, N. L. Working models of attachment: Implications for explanation, emotion, and behavior. Journal of Personality and Social Psychology, 71, 1996, 810-832. http://dx.doi.org/10.1037/0022-3514.71.4.810

[30] Diener, E., Enmors, R. A., Larsen, R. J., \& Griffin, S. The Satisfaction With Life Scale. Journal of Personality Assessment, 49, 1985, 71-75. http://dx.doi.org/10.1207/s15327752jpa4901_13

[31] Koker, S. "Comparison of life satisfaction among normal and problematic adolescents." Yayınlanmamış yüksek lisans tezi. Unpublished Master's Thesis, Ankara: Ankara Üniversitesi Sosyal Bilimler Enstitüsü. (in Turkish), 1991.

[32] Hills, P., \& Argyle, M. The Oxford Happiness Questionnaire: A compact scale for the measurement of psychological well-being. Personality and Individual Differences, 33, 2002, 1073-1082. http://dx.doi.org/10.1016/S0191-8869(01)00213-6

[33] Seker, H., \& Gencdogan, B. Developing Measurement Instruments in Psychology And Education. Ankara, Nobel Yayın Dağıtım (in Turkish). 2006.

[34] Doğan, T., \& Çötok, N. A. Adaptation of the Short Form of the Oxford Happiness Questionnaire into Turkish: A Validity and Reliability Study. Türk Psikolojik Danışma ve Rehberlik Dergisi, 4, 2011, 165-172 (in Turkish). http://dergipark.ulakbim.gov.tr/tpdrd/article/view/1058000176/1058000178

[35] Ekici, S., Sari, I., Soyer, F., Colakoglu, T. Do multiple intelligences predict leadership behaviors of physical education and sport students in Turkey? Energy Education Science and Technology Part B: Social and Educational Studies, 4, 2012, 1949-1960. https://www.researchgate.net/publication/260907706

[36] Hamurcu, H., Gunay, Y., Ozyilmaz, G. \& Altinisik, I. (Buca eğitim fakültesi fen bilgisi ve sınıf öğretmenliği bölümü öğrencilerinin çoklu zeka kuramına dayalı profilleri. V. Ulusal Fen Bilimleri ve Matematik Eğitimi Kongresi, (in Turkish). 2002, 334-338

[37] Sozen, H., Sozen, M. Tekat, A. Comparison Of The Profiles Of The Potential Teachers In Different Disciplines Based On Multiple Intelligences Theory (Samsun City Sample). Procedia Social and Behavioral Sciences, 1, 2009, 943-948. http://dx.doi.org/10.1016/j.sbspro.2009.01.167

[38] Furnham, A., Clark, K., \& Bailey, K. Sex differences in estimates of multiple intelligences. European Journal of Personality, 13, 1999, 247-259.

[39] Furnham, A., Tang, T. L-P., Lester, D., O’Connor, R., \& Montgomery, R. Estimates of ten multiple intelligences: Sex and national differences in the perception of oneself and famous people. European Psychologist, 7, 2002, 245-255. https://doi.org/10.1027//1016-9040.7.4.245

[40] Furnham, A., \& Buchanan, T. Personality, gender and self-perceived intelligence. Personality and Individual Differences, 39, 2005, 543-555. https://doi.org/10.1016/j.paid.2005.02.011

[41] Furnham, A., \& Chamorro-Premuzic, T. Estimating one's own and one's relatives' multiple intelligence: A study from Argentina. Spanish Journal of Psychology, 8, 2005, 12-20. http://revistas.ucm.es/index.php/SJOP/article/viewFile/SJOP0505120012A/29152

[42] Sellars, M. Intelligence for the 21st century: A discussion of intrapersonal and emotional intelligences. International Journal of Learning, 15, 2008, 79-87.

[43] Sellars, M., \& Sanber, S. Intrapersonal Intelligence. International Journal of Learning, 12, 2006, $307-319$.

[44] Kafetsios, K. \& Sideridis, D.G. Attachment, social support and well-being in young and older adults. Journal of Health Psychology, 11, 2006, 863-876. http://journals.sagepub.com/doi/pdf/10.1177/1359105306069084 
[45] Kankotan, Z.Z. The role of attachment dimensions, relationship status, and gender in the components of subjective well-being. Master Thesis, Middle East Technical University, Ankara, 2008. https://etd.lib.metu.edu.tr/upload/3/12609299/index.pdf

[46] Gnilka, P., Ashby, J., \& Noble, C. Adaptive and maladaptive perfectionism as mediators of adult attachment styles and depression, hopelessness, and life satisfaction. Journal of Counseling \& Development, 91, 2013, 78-86. http://dx.doi.org/10.1002/j.15566676.2013.00074.x

[47] Wright,S.L., Firsick,D.M. , Kacmarski, J.A.,\& Jenkins-Guarnieri, M.AEffects of attachment on coping efficacy, career decision selfefficacy, and life satisfaction. Journal of Counseling \& Development, 95, 2017, 445-456. http://dx.doi.org/10.1002/jcad.12159

[48] Hazan,C., Shaver, P.R. Romantic love conceptualized as an attachment process. Journal of Personality and Social Psychology, 52, 1987, 511-524. http://dx.doi.org/10.1037/0022-3514.52.3.511 